\title{
GRANULAR CELL TUMOR - CHEEK: A CASE REPORT
}

Shankar Tati ${ }^{1}$, A. Shobhan Babu², D. Ranganath Swamy33, S. Indira Devi ${ }^{4}$, Manish Kumar ${ }^{5}$

\section{HOW TO CITE THIS ARTICLE:}

Shankar Tati, A. Shobhan Babu, D. Ranganath Swamy, S. Indira Devi, Manish Kumar. "Granular Cell TumorCheek: A Case Report". Journal of Evolution of Medical and Dental Sciences 2014; Vol. 3, Issue 56, October 27; Page: 12821-12825, DOI: $10.14260 /$ jemds/2014/3701

ABSTRACT: INTRODUCTION: Granular Cell Tumor can develop in any part of the body most of cases occur in head and neck region(3,4), it is also known as Granular Cell Myoblastoma, Granular Cell Schwanoma, Granular Cell Tumor is one whose histological origin has not yet been determined, most of the cases are benign (98\%) and reported malignant cases are rare, occurring in only $1 \%$ or $2 \%(1,2)$ CASE PRESENTATION: A 36 years old male patient came to Govt. ENT Hospital, Hyderabad with swelling of (L) cheek since 02 years. Swelling was excised by lateral rhinotomy and diagnosed only by Immunohistochemistry study, FNAC and HPE reports are different from granular cell tumor. DISCUSSION: Granular Cell Tumor is a rare tumor, mainly occur in Head \& Neck region, within head and neck, tongue is the most common site, total excision is the treatment of choice. Malignant Transformation is very rare. Here we are presenting a case of Granular Cell Tumor in male patient in the subcutaneous tissue of the (L) cheek. CONCLUSION: Granular Cell Tumor is a Neoplasm that develops in the soft tissues, mainly in the skin, oral cavity and gastointestinal tract, but the Tumor is relatively rare, complete excision is the treatment of choice.

KEYWORDS:Myoblastoma, Nodular Fascitis, Cowden Syndrome, fibroblasts, Lateral Rhinotomy.

CASE REPORT: A 36 years old male patient residing at Shanthi Nagar, Kadapa (dist) of Andhra Pradesh presented to ENT OPD with complaints of swelling of the (L) left Cheek since 02 years, which was started as a small nodule, slowly progress to present size. (Fig. No.1)

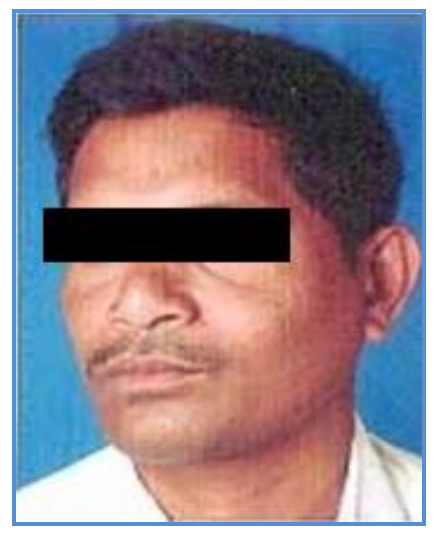

Figure 1

Patient was subjected for necessary investigations along with FNAC shows Histiocytoma (L) cheek and patient posted for excision biopsy and sent for Histo pathological Examination as advised by the Professor of Pathology since the FNAC report was inconclusive. 


\section{CASE REPORT}

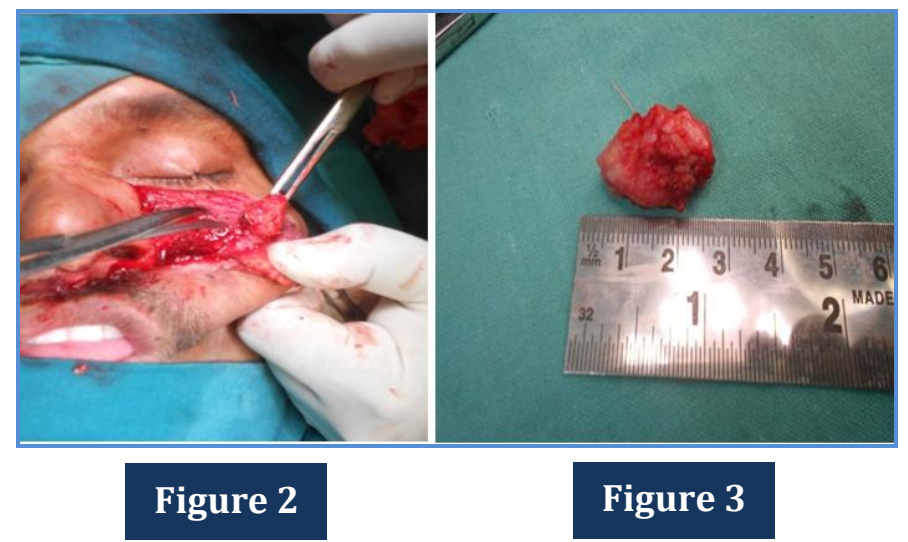

Subsequently patient was admitted and posted for excision under general anesthesia through Lateral Rhinotomy approach (Fig. No. 2), a tumor size about $2.5 \mathrm{~cm} \times 2 \mathrm{~cm}$ globular in size hard in nature (Fig. No.3), present in between the soft tissues of the left cheek removed in to and sent for HPE, wound was closed in layers, post-operative recovery was uneventful, sutures were removed on $7^{\text {th }}$ day patient was discharged. The HPE report was Nodular Fasciitis and advised for IHC study. The blocks were sent to Nizam's Institute of Medical Sciences Hyderabad for IHC study and for final reporting.
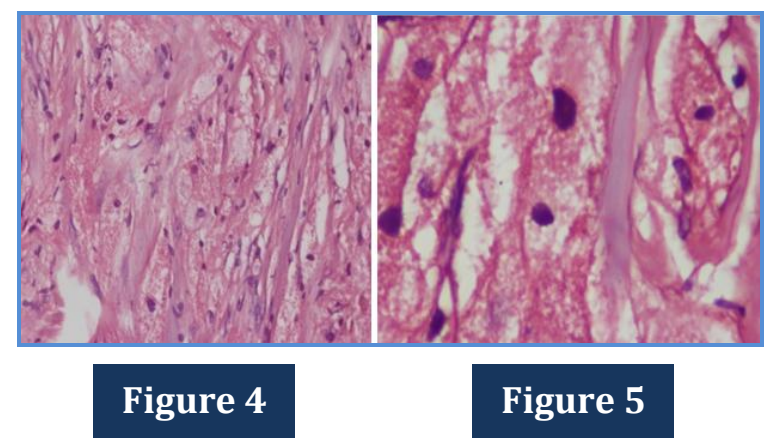

HPE REPORT: Sections show fairly circumscribed lesion with skeletal muscle bundle on one side. Lesion is comprised of irregular bundles of spindle shaped cells. Nuclei are round to oval with mild nuclear atypia. Atypical mitosis not noted. The stroma shows collagenous tissue. Few cells show granular and vacuolated cytoplasm. Few blood vessels are noted and there is perivascular lymphomonocuclear inflammatory infiltrate. There is no evidence of necrosis. (Fig. No.4 \& 5)

IMPRESSION: Benign Spindle cell lesion possibly Nodular - Fasciitis.

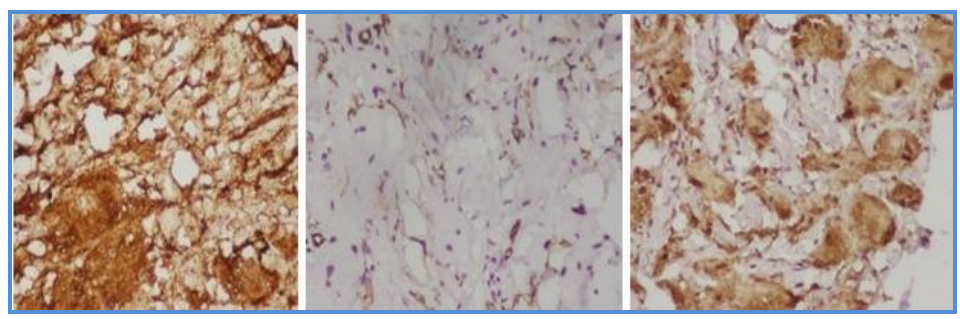

S - 100 SMA CD 68.

\section{Figure 6}


IHC REPORT:H\&E sections reviewed along with IHC stain along with spindle shaped cells there are nests showing aggregates of polygonal cells with eosinophilia granular cytoplasm and small pyknotic nuclei. There is mild nuclear atypia however mitosis is minimal. There is no evidence of necrosis or vesicular nuclei with prominent nucleoli. (Fig. No. 6)

S100 - Intense Positivity in Granular Cells and Spindle Cells.

CD68 - Positive in Granular Cells

SMA - Positive only in Blood Vessels and Negative in Granular Cells.

IMPRESSION: Correlating histomorphology with IHC results, features are consistent with Granular Cell Tumor.

DISCUSSION: The Granular Cell Tumor can develop in any part of the body and $50 \%$ of all cases occur in the skin, head and neck area especially in the Tongue(6) The next most common location that lesions are found in the head and neck area is the larynx (10\%) Granular Cell Tumor also found in the internal organs, particularly in the upper aerodiagestive track. The Granular Cell Tumor was reported by Abrikossoff (5) in 1926 by the name of granular cell myoblastoma.

It is also known as Abrikossoffis Tumor, Granular Cell Myblastoma Granular Cell Nerve Sheath Tumor, and Granular Cell Schwanoma. They account for an incidence of $0.5 \%$ soft tissue tumor and it has been reported that they primarily occur in or beneath the skin or in the sub mucous of the Tongue, Throat, chest wall and Bronchus. The tumor is commonly found in the age of 10 to 50 years, more often in women then in man(7), when it develops beneath the epidermics or mucous membrane it can lead to proliferation of squamous cells and mimic squamous cell carcinoma.

The cytoplasm of a granular cell tumor contains ill-defined, spindle- shaped or polygonal, vacuolated nuclei and eosinophilic granules. These granules are strongly positive for the PAS reaction and immunohistochemistry reveals strong postivities for S-100 protein and neuron-specific enolase. These tumors also stain for vimentin, myelin-associated glycoprotein (Leu-7) and CD68 (KP-1) $(8,9)$

Granular Cell Tumors are almost always benign, but malignant manifestations are found in 1$2 \%$ of the patients $(1,2)$. They are preferentially located in the skin and subcutaneous region. They involve the regional lymph nodes, although distal metastasis is uncommon. Malignancy is suspected for a series of factors (Garin et al., 1992).

1. Cases of tumors macroscopically similar to benign Granular Cell Tumors however quickly relapsing locally after surgical removal.

2. Tumors above 4cm, Gamboa (1955) and Batsaki and Manning (1986) reported GCT cases with malignant clinical and histological characteristics, with larger tumors (averaging $9 \mathrm{~cm}$ in diameter) in relation to benign Granular Cell Tumors.

3. Tumor evolving slowly that suddenly begins to grow quickly.

4. Presence of distal metastasis.

5. Presence of atypia and pleomorphic, although not always present in malignant Granular Cell Tumor.

About $2 \%$ of all granular cell tumors cases are malignant. A tumor $3 \mathrm{~cm}$ or less in size can be regarded as benign. However, if the tumor grows rapidly and forms an ulcer, malignancy should be suspected. Sonobe and colleagues divided malignant granular cell tumors into two groups: those that are malignant both histologically and clinically, and those that are histologically benign but clinically 
malignant. The most common metastasis sites of malignant granular cell tumor are the lymph nodes, followed by the lungs.

Insufficient tumor resection often results in local recurrence, and has a tendency to spread both lymphogenously and hematogenously. Reportedly chemotheraphy and radiotherapy treatments cannot be expected to be effective, with surgical resection being the primary option. Resection with adequate margins is necessary because the tumor has no capsule and is proliferation invasive. Once the diagnosis of a benign granular cell tumor is confirmed, complete surgical resection becomes the appropriate treatment.

During removal, securing a negative free margin is a strongly demanded goal, Radiation therapy or chemotherapy is not recommended because it may be less responsive or induce malignant transformation (10). Even though surgical resection is performed properly, there is an $8-21 \%$ recurrence rate, usually at the primary site. Some of these recurrences may be due to a failure in to diagnose multiple lesions. Moreover, in cases of inadequate removal with the remnant of the tumor at the resection margins, it may recur, for differential diagnosis of a granular cell tumor in the subcutaneous tissue and muscle, candidates includes malignant fibrous histiocytoma, alveolar soft part sarcoma, desmoid, granulomatous and nodular fasciitis.

CONCLUSION: Granular Cell Tumor is a neoplasm that develops in the soft tissues mainly in the skin, oral cavity, and gastrointestinal Tract, but the Tumor is relatively rare. Granular Cell Tumor in our case was benign and found in male patient, since it is more commonly seen in female, and no recurrence after resection has been formed.

\section{REFERENCES:}

1. Enzinger FM, Weiss SW. Granular cell tumor. In:Enzinger FM, Weiss SW, editors. Soft tissue tumors $3^{\text {rd }}$ ed. St.Louis:Mosby; 1995. PP.864 - 875.

2. Kataoka A, Koike M, Kuranuki K, Wakayama K, Yamada S, Akasaka Y. A case of malignant granular cell tumor arisen in the chest wall (in Japanese with English abstract) JJpnSurg Assoc. $2005 ; 66: 2403-2406$.

3. Berkowitz SF, Hirsh BC, Vonderheid E.Granular cell tumor, a great masquerader. Cuits. 1985 Apr, 35 (4):355 -356. (PubMed).

4. Strong EW, McDivitt RW, Brasfield RD. Granular Cell myoblastoma. Cancer. 1970 Feb; 25(2):415 - 422 (PubMed).

5. Abrikossoff A. UberMyome, Ausgehend von der quergestreiften wilkuerlichen muskkulatur. Virchows Arch pathol Anat. 1926;260:215 - 233. Aug; 98(8 Pt1):810 - 814. (PubMed).

6. Lack EE, Worsham GF, Callihan MD, Crawford BE, Klappenbach S, Rowden G, Chun B. Granular Cell Tumor: a clinic pathologic study of 110 patients. J SurgOncol. 1980; 3:301 - 316.

7. Fisher ER, Wechser H. Granular Cell myblastoma-amisnomer. Electron microscopic and hisochemical evidence concerning its Schwann cell derivation and nature (granular cell schwannoma) Cancer.1962 Sep-Oct, 15:936 - 954. (PubMed).

8. Mazur MT, Shultz JJ, Myers JL. Granular cell tumor. Immunohistochemical analysis of 21 benign tumors and one malignant tumor. Arch pathol Lab Med. 1990 Jul; 114 (7):696. (PubMed). 
9. Fanburg-Smith JC, Meis-Kindblom JM, Fante R, Kindblom LG. Malignant granular cell tumor of soft tissue: diagnostic criteria and clinic pathologic correlation. Am J Srugpathol. 1998 Jul:22(7):779 -794. (PubMed).

\section{AUTHORS:}

1. Shankar Tati

2. A. ShobhanBabu

3. D. RanganathSwamy

4. S. Indira Devi

5. Manish Kumar

\section{PARTICULARS OF CONTRIBUTORS:}

1. Professor, Department of ENT, Osmania Medical College, Hyderabad.

2. Associate Professor, Department of ENT, Osmania Medical College, Hyderabad.

3. Assistant Professor, Department of ENT, Osmania Medical College, Hyderabad.

4. Former Professor, Department of ENT, Osmania Medical College, Hyderabad.

5. Assistant Professor, Department of ENT, Osmania Medical College, Hyderabad.

\section{NAME ADDRESS EMAIL ID OF THE} CORRESPONDING AUTHOR:

Dr. T. Shankar, \# 12-5-149/6/A,

Flat No. 201,

Sajja's Ambiance,

Vijayapuri, Tarnaka,

Hyderabad-500017.

Telangana, India.

Email: drshankar_ms@yahoo.com

Date of Submission: 07/10/2014.

Date of Peer Review: 08/10/2014.

Date of Acceptance: 22/10/2014.

Date of Publishing: 27/10/2014. 